\title{
Pre-Weaning Growth of Criollo Tropical Milking Calves fed with Milk from Silvopastoral Systems
}

\author{
Becerril-Pérez, Carlos M. ${ }^{1}$; Sánchez-Gómez, Adrián ${ }^{1}$; Morales-Trejo, Fredy ${ }^{1}$; \\ Vargas-Romero, Juan M. ${ }^{2}$; Platas-Rosado, Diego E. ${ }^{1}$; Rosendo-Ponce, Adalberto ${ }^{1^{*}}$ \\ ${ }^{1}$ Colegio de Postgraduados, Veracruz Campus. Manlio Fabio Altamirano, Veracruz, Mexico. \\ ${ }^{2}$ Universidad Autónoma Metropolitana, Iztapalapa Unit. Iztapalapa, Mexico City, Mexico. \\ *Corresponding author: arosendo(acolpos. $\mathrm{mx}$
}

\begin{abstract}
Objective: Tropical Milking Calf (LT) growth and milk consumption and chemical composition were analyzed in two shepherding systems.

Methodology: 26 LT cows were used in rotational shepherding in monoculture (PRM) and intensive silvopastoral system (SSPi). Cows were milked by hand once per day in the morning with the presence of the calf, which consumed milk from one nipple. Live weight (PV), daily weight gain (GDP), milk consumption (CL) by the calf and the chemical composition of the milk were studied.

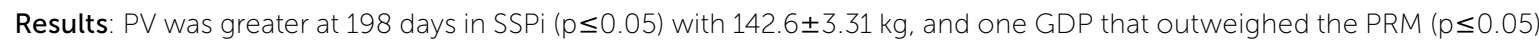
in $80 \mathrm{~g} \mathrm{per} \mathrm{day}^{-1}$. There were no differences in $\mathrm{CL}(\mathrm{p}>0.05)$. Non-fatty solids, protein, lactose and total solids were greater ( $p \leq 0.05$ ) for SSPi with $8.1 \pm 0.07,3.0 \pm 0.02,4.5 \pm 0.04$ and $12.1 \pm 0.21 \%$, respectively; although fat was similar $(3.7$ and 3.3 $\%, p>0.05)$ in both systems.

Implication: The chemical composition of milk should be assessed from the nutritional perspective for the calf and the more appropriate techniques for its measurement should be implemented.

Conclusions: PV and GDP were greater in SSPi than in PRM due to the chemical composition and not the amount of ingested milk. The chemical composition of milk affected the pre-weaning growth of calves. The tropical milking race and SSPi are an alternative for tropical livestock raising in warm weathers.
\end{abstract}

Keywords: warm weathers, livestock raising, river tamarind, gene resources, agroecology systems.

\section{INTRODUCTION}

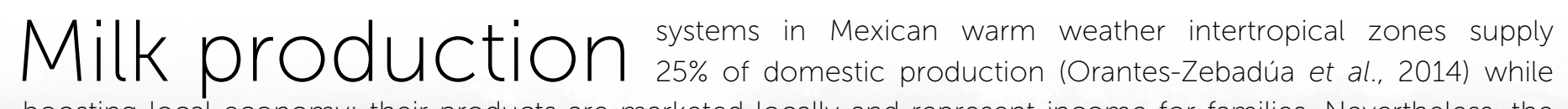
boosting local economy; their products are marketed locally and represent income for families. Nevertheless, the seasonality of the rain period, the use of technology, managerial abilities and local traditions affect their productivity

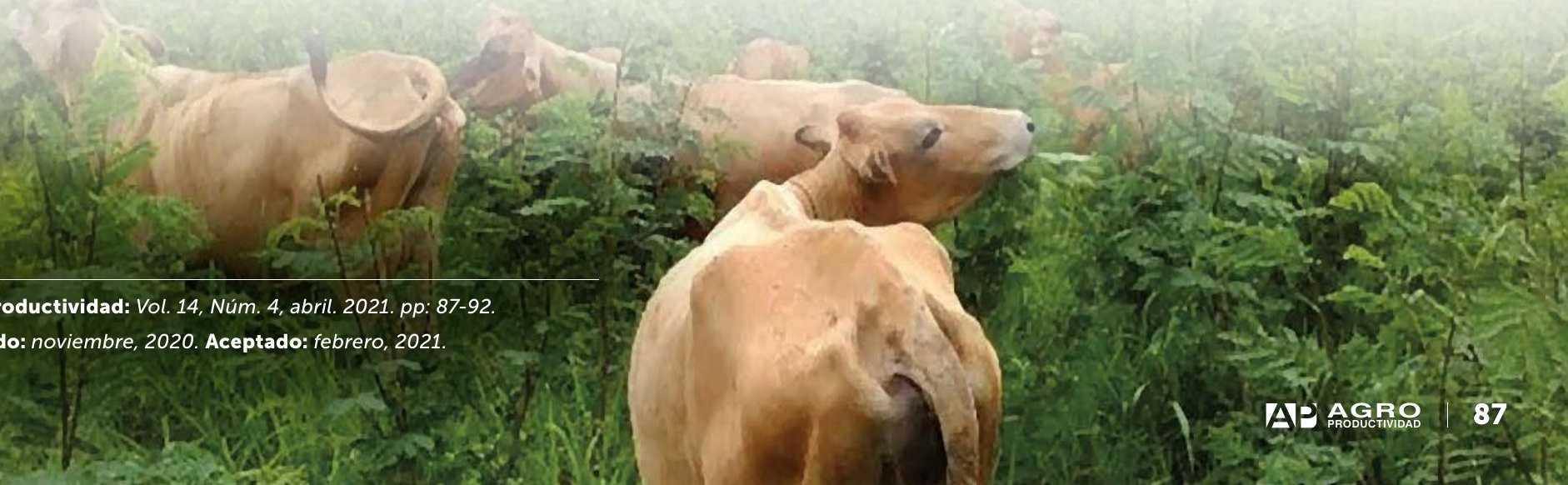


and may have an adverse incidence in the preservation of natural resources (Murgueitio et al., 2015). Tropical milk production is characterized by the flexibility of its zootechnical function (Martínez et al., 2012), due to the fact that feeding the calves before the milking is used to stimulate the descent of milk and both milk is produced and calves are weaned. Calf growth from birth to weaning is determined by the amount and chemical composition of the consumed milk, which in turn depends on the feeding by the mother (Martínez et al., 2012; Díaz et al., 2014; Orantes-Zebadúa et al., 2014). The calf is allowed to consume residual milk after the milking, which is regulated by the depth of the milking and number of milked nipples, which influences the daily weight gain that may be lower than $365 \mathrm{~g}^{\text {per day }}{ }^{-1}$ (Salamanca et al., 2011). Although supplements may be used to contribute to feeding calves and destining more milk for sale and obtainment of greater income, both supplements and the financial resource for their acquisition should be available for the producer (Guarneros et al., 2017).

The criollo Tropical Milking $(\mathrm{LT})$ race is adapted to shepherding systems, requires little inputs, its productive capacity is $1174 \pm 11.4 \mathrm{~kg}$ of milk per breastfeeding, reason why it is a gene alternative for

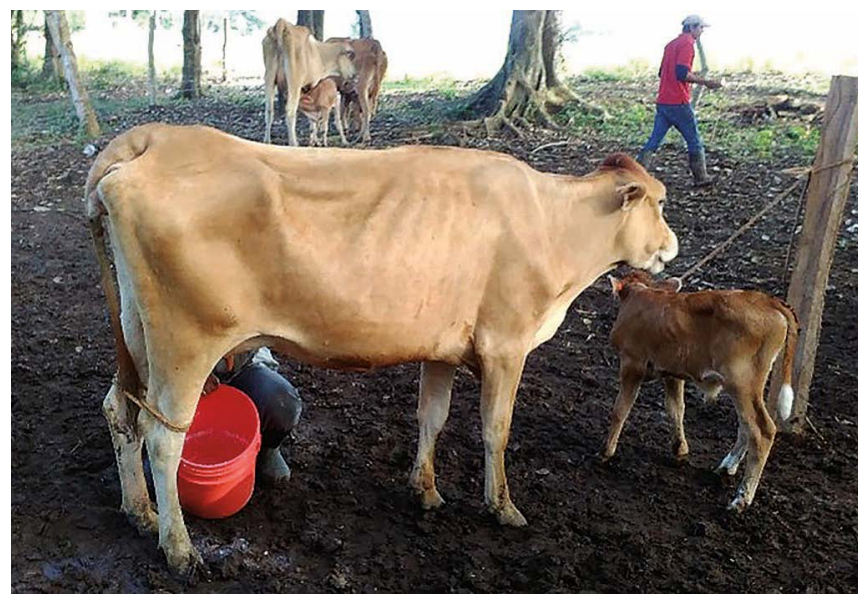

Figure 1. Criollo Tropical Milking cow hand milking with the presence of the calf in the "El Huilango" land lot, Cotaxtla, Veracruz, Mexico. composition of milk in rotational shepherding systems in monoculture and intensive silvopastoral system.

\section{MATERIALS AND METHODS}

The study was performed from June to December 2018 in the "El Huilango" land lot, Cotaxtla, Veracruz, Mexico $\left(18^{\circ} 53^{\prime} \mathrm{N}, 96^{\circ} 15^{\prime} \mathrm{O}\right)$, a 30 altitude. It has a subhumid warm weather Awo (w) (i')g, with rains in summer (García, 1988), with mean annual temperature and rains of 25.4 ${ }^{\circ} \mathrm{C}$ and $1042 \mathrm{~mm}$

26 first-birth LT cows and 40.45 \pm 0.67 months of age. At $24 \mathrm{~h}$ after birth they entered a paddock with pará grass (Brachiaria mutica [Forssk.] Stapf), where they stayed while they produced colostrum and then they were transferred to the paddock according to the corresponding shepherding system. Calf identification and weight measurement upon birth were performed on the first 24 hours of life, they consumed colostrum and milk once per day until reaching 10 days of life. Then, they were transferred to giant star grass (Cynodon plectostachyus [K.Schum.] Pilg.) and native vegetation paddock, where they remained apart from their mother during the entire study. Cows were milked by hand once per day with tropical milking (Rosendo-Ponce \& Becerril-Pérez, 2015). Intensive silvopastoral systems (SSPi) meet agroecology productive and environmental functions upon combining herbaceous strata with local and improved grass, as well as shrub strata such as river tamarind (Leucaena leucocephala [Lam.] de Wit); SSPis are an alternative for improving animal productivity and mitigating climate change effects. SSPis and the LT race may be an alternative for sustainable milk production in the warm weather intertropical region. Upon shepherding in a SSPi, LT cows may increase their production and milk quality, which would in turn power the growth and daily weight gain of calves due to the fact that, during the first 90 days of life, their feeding depends mainly on milk (HerasTorres et al., 2008). Therefore, the objective hereof was to compare growth and consumption of criollo Tropical Milking calves and determining the chemical the presence of the calf, and calves consumed milk from one nipple (Figure 1). As of 90 days after birth, calves were supplemented with ground corn offered individually in 760 g per day ${ }^{-1}$

Thirteen cows were randomly allocated to each rotational shepherding system in monoculture (PRM) in SSPi and were given ad libitum water and minerals. Each system had four 1-ha paddocks, with an electric fence and distributed randomly in the area of study. The PRM had Megathyrsus maximus grass only (Jacq.) B.K. Simon \& S.W.L. Jacobs CV. Mombasa (Figure 2a); the SSPi had M. maximus grass in the herbaceous stratum and an arrangement or rows at a distance of $1.6 \mathrm{~m}$ with Leucaena leucocephala (Lam.) de Wit, with a density of $8400 \pm 184$ plants ha ${ }^{-1}$ (Figure 2b). The occupation and paddock resting period was of 4 and 28 days during the 

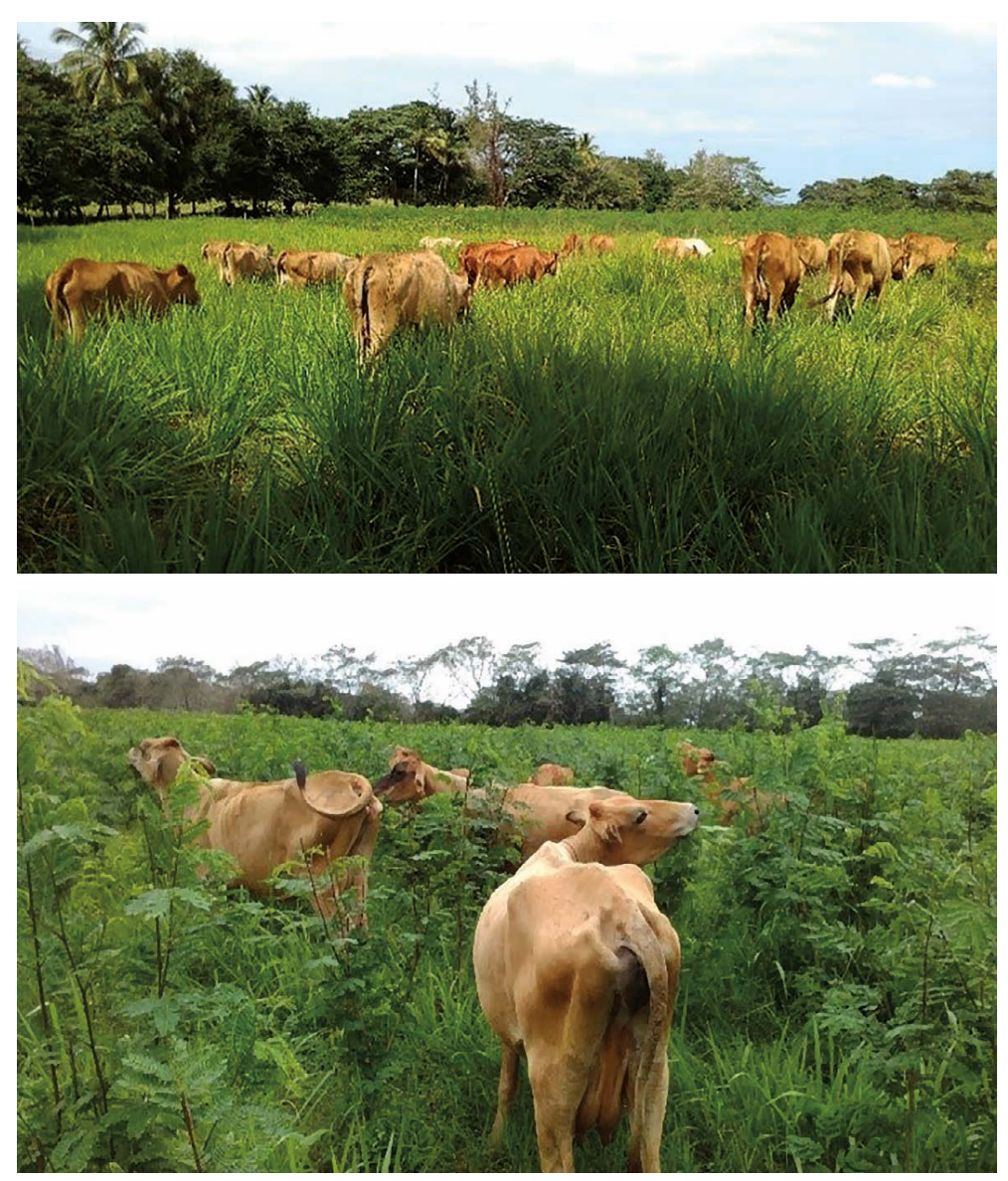

Figure 2. Tropical Criollo Milking cows in rotational shepherding systems in a) grass monoculture and b) intensive silvopastoral system in the "El Huilango" land lot, Cotaxtla, Veracruz, Mexico.

humid warm season (June - October) and 5 and 35 days during the dry cold season (November - December). No fertilization nor ancillary irrigation were applied in both systems.

The live weight of calves (PV, kg) was measured with a digital scale (EziWeigh5i, Tru-Test ${ }^{\circledR}, \mathrm{NZ}$ ) before the milking every 28 days. The weight was adjusted through the equation described by Salamanca et al. (2011). The daily weight gain (GDP, g per day $^{-1}$ ) were calculated every 28 days with the equation:

$$
G D P=[(P R P-P R P A) /(D E P)]
$$

where: $P R P=$ Current live weight $(\mathrm{kg}), P R P A=$ Previous live weight $(\mathrm{kg})$ y $D E P=$ Days between weighing. Milk consumption per calf $\left(\mathrm{CL}, \mathrm{kg} \mathrm{d}^{-1}\right)$ was estimated at 90 and 180 days, through the difference in calf weight and before sucking for two consecutive days, and one milk sample was taken per thoroughly milked cow. Milk was refrigerated at $5{ }^{\circ} \mathrm{C}$ and transferred to the laboratory, where fat $(G)$, protein $(P)$, lactose $(L)$, non-fatty solid
(SNG) and total solid (ST) content was determined with a Lactoscan MCC ultrasonic milk analyzer (Mllktronic, Bul).

In order to analyze GDP, CL, G, P, L, SNG and ST, a model that included the stationary effects of the calf shepherding system and sex was used; PV was analyzed with a mixed model with repeated measurements with covariance structure in an integrated autoregressive mobile average model. Data were processed with GLM and MIXED procedures of SAS ${ }^{\circledR} 9.3$ (SAS Institute, 2010). Treatment measure comparison was made with Tukey's test $(\alpha=0.05)$.

\section{RESULTS AND DISCUSSION}

Birth weight of LT calves was of $25.68 \pm 1.03 \mathrm{~kg}$ in females and $29.07 \pm 1.05 \mathrm{~kg}$ in males. These birth weights were lower than cross-bred genotypes of European races with cebuine breeds of $31.1 \pm 4.7$ females and $31.66 \pm 0.23 \mathrm{~kg}$ in males (MadridBury et al., 2007; Arce et al., 2017). The smallest size of native races may be an adaptative feature of natural selection at adverse warm tropical conditions. The live weight of LT calves in both shepherding systems appears in Table 1. During the first 60 days, calves almost doubled their birth weight. Heras-Torres et al. (2008) describe a primary slow-growth stage, attributed to a non-ruminant to ruminant transition and a more developed immune system; in this study, the slow growth period occurred from day 60 to 120; as of 120 days, calves fed with milk from both shepherding systems showed an accelerated growth. Nevertheless at 170 and 198 days, calves fed with SSPi had a PV greater than in PRM ( $p \leq 0.05$, Table 1$)$.

PV at 98 days for calves fed with SSPi milk was greater than $121.4 \pm 32.5 \mathrm{~kg}$ at 224 days of age for domestic cow vs zebu (Osorio-Arce and Segura-Correa, 2008), fed with one nipple and supplemented with commercial feed. Saddy et al. (2015) reported weights of 105.7 \pm 14.22 and $109.7 \pm 13.65 \mathrm{~kg}$ at 190 days, supplemented with 0.869 and $0.980 \mathrm{~kg}$ of commercial concentrate of 10 and $20 \%$ raw protein $(P C)$ for CF1 Holstein $\times$ Brahman cross breeds, which suggests that it feasible to obtain a better pre-weaning growth for LT calves in SSPi.

GDP in SSPi was greater than $99 \mathrm{~g}$ per day ${ }^{-1}$ than the one obtained in the PRM system, which meant 18.11 $\mathrm{kg}$ more of PV upon weaning (Table 2). Romosinuano 


\begin{tabular}{|c|c|c|c|c|}
\hline Day & $\begin{array}{l}\text { Rotational } \\
\text { shepherding in } \\
\text { monoculture }\end{array}$ & $\begin{array}{c}\text { Intensive } \\
\text { silvopastoral } \\
\text { system }\end{array}$ & $\begin{array}{c}\text { Standard } \\
\text { error }\end{array}$ & $p$ value \\
\hline 0 & 27.8 & 27.4 & 3.22 & 0.943 \\
\hline 22 & 42.2 & 41.2 & 3.22 & 0.832 \\
\hline 60 & 49.1 & 52.1 & 3.22 & 0.510 \\
\hline 88 & 52.7 & 58.7 & 3.22 & 0.189 \\
\hline 116 & 63.7 & 69.1 & 3.22 & 0.233 \\
\hline 142 & 76.1 & 83.7 & 3.26 & 0.105 \\
\hline 170 & $90.4 a$ & $103.9 b$ & 3.29 & 0.004 \\
\hline 198 & $123.6 a$ & $142.6 b$ & 3.31 & 0.001 \\
\hline
\end{tabular}

$a, b$ Different letters on the same row indicate differences $(p \leq 0.05)$.

calves cross-bred with Jersey calves during the restricted 5-hour breastfeeding had a GDP of $299 \mathrm{~g} \mathrm{per} \mathrm{day}^{-1}$ and a weaning weight adjusted to $106.15 \mathrm{~kg}$ at 270 days (Salamanca et al., 2011), lower than LT calves; genotype, technology and environment affect calf response.

There were no differences ( $p>0.05$ ) in GDP for females and males, similar to zebu cross-bred calves (Cárdenas et al., 2015); nevertheless, other studies state differences in GDP and weaning weight between sexes (HerasTorres et al., 2008; Salamanca et al., 2011). CL in LT calves was similar in both shepherding systems ( $p>0.05$, Table 2) and at $3 \pm 0.2 \mathrm{~kg}$ per day ${ }^{-1}$ for cross-bred calves fed with one nipple for the first 100 days of life (Chirinos et al., 2011);nevertheless, their GDP was of $287 \pm 20 \mathrm{~g}$ per day $\mathrm{d}^{-1}$, supplemented with $300 \mathrm{~g}$ of concentrated feed (20\% PC), lower than the GDP of LT calves The difference in GDP obtained in PRM and SSPI systems in relation to other studies, evidence that the chemical composition of milk is a determining factor for calf growth (Table 3) (Chirinos et al., 2011; Salamanca et al., 2011).

Thechemicalcomposition of milkin bothshepherding systems was not different in fat ( $p>0.05)$; results match those of 3.7 and $3.6 \pm 0.05$ for milk produced in a PRM and an SSPi system with cross-bred cows supplemented with concentrate (Mohammed et al., 2016). Prieto-Manrique et al. (2016) obtained 2.88 and $4.41 \%$ in similar shepherding conditions, while Hernández and Ponce (2004) obtained 4.07士0.16 and $4.2 \pm 0.22 \%$ fat for PGM and SSPi, respectively. The proportion of volatile acetic and propionic fatty acids in rumen determined the milk fat content (Ramos et al., 1998); the difference in fat content with respect to other studies may be attributed to the forage-concentrate ratio and the amount of fiber in diet, due to the fact that the proportion of acetic and propionic acid in rumen is sensitive to these factors; in this sense, legumes affect the quality of milk as their degradability in rumen is more similar than that of grain, as it shows lower neutral effective detergent fiber compared with grass (Silva et al., 2016).

SNGs were greater in the SSPi at 90 and 180 days ( $p \leq 0.05)$, due to the fact that their main components, protein and lactose, were also found in greater amounts

\begin{tabular}{|c|c|c|c|c|c|}
\hline Characteristic & $\begin{array}{l}\text { Intensive rotational } \\
\text { shepherding }\end{array}$ & Standard error & $\begin{array}{c}\text { Intensive } \\
\text { silvopastoral } \\
\text { system }\end{array}$ & Standard error & $p$ value \\
\hline Daily weight gain ( $\mathrm{g} \mathrm{d}^{-1}$ ) & $488.7 a$ & 0.12 & $587.7 \mathrm{~b}$ & 0.14 & 0.01 \\
\hline Milk consumption in 90 days $\left(\mathrm{kg} \mathrm{d}^{-1}\right)$ & $2.7 a$ & 0.21 & $3.2 \mathrm{a}$ & 0.21 & 0.10 \\
\hline Milk consumption in 180 days $\left(\mathrm{kg} \mathrm{d}^{-1}\right.$ ) & $2.6 a$ & 0.23 & $2.8 a$ & 0.21 & 0.54 \\
\hline
\end{tabular}

$a, b$ different letters on the same row indicate differences $(p \leq 0.05)$.

Table 3. Chemical composition of milk consumed by Tropical Milking calf in two shepherding systems during their pre-weaning stage at 90 and 180 days.

\begin{tabular}{|c|c|c|c|c|c|c|c|c|c|c|}
\hline & \multicolumn{2}{|c|}{ Fat } & \multicolumn{2}{|c|}{ Non-fatty solids } & \multicolumn{2}{|c|}{ Protein } & \multicolumn{2}{|c|}{ Lactose } & \multicolumn{2}{|c|}{ Total solids } \\
\hline & 90 & 180 & 90 & 180 & 90 & 180 & 90 & 180 & 90 & 180 \\
\hline Intensive rotational shepherding & $3.5^{\mathrm{a}}$ & $3.7^{\mathrm{a}}$ & $7.9^{b}$ & $8.0^{\mathrm{b}}$ & $2.9^{b}$ & $2.9^{b}$ & $4.3^{b}$ & $4.4^{b}$ & $11.4^{\mathrm{b}}$ & $11.7^{\mathrm{a}}$ \\
\hline Intensive silvopastoral system & $3.9^{a}$ & $3.3^{a}$ & $8.1^{a}$ & $8.5^{a}$ & $3.0^{a}$ & $3.1^{a}$ & $4.5^{\mathrm{a}}$ & $4.7^{a}$ & $12.1^{a}$ & $11.8^{a}$ \\
\hline Standard error & 0.2 & 0.3 & 0.1 & 0.1 & 0.02 & 0.04 & 0.04 & 0.07 & 0.21 & 0.25 \\
\hline
\end{tabular}

a.b different letters on the same column indicate a significant amount $(p \leq 0.05)$. 
$(p \leq 0.05)$. Cows fed in SSPi have access to a diet with greater protein content (Murgueitio et al., 2015), which may be related to the difference in protein and lactose content in milk between shepherding systems; the mammary gland synthetizes milk protein from the availability of aminoacids and greater propionic acid levels increase lactose synthesis (Ramos et al., 1998); SNG, protein and lactose contents were similar in PRM and SSPi with 8.1, 2.9 and $4.3 \%$ and 8.2, 3.0 and $4.5 \%$ (Mohammed et al., 2016).

ST were greater in SSPi milk at 90 days; this difference in milk chemical composition influenced the productive behavior of calves, as they depend on the consumed milk; albeit there were no differences between shepherding systems at 180 days $(p>0.05)$. Protein and lactose amounts were greater for SSPi related to greater GDP of calves. Rumen begins to become functional at 60 days of life in calves, reason why the daily ingestion of milk is considered to be a diet supplement, capable of favoring greater growth rates (Cárdenas et al., 2015). Martínez et al. (2010) found a significant correlation between weight at 210 days and protein present in milk. Estimated STs were similar than those obtained by Mohammed et al. (2016), although lower than $1 \%$ for PRM and $0.5 \%$ for SSPi (Hernández \& Ponce, 2004), the difference is attributable to a different supplementation.

\section{CONCLUSIONS}

In an intensive silvopastoral system with legume availability, criollo Tropical Milking calves had a greater weight at 180 days and a greater daily weight gain, although milk consumption per day was similar than that of calves within a grass monoculture shepherding systems. The chemical composition of milk for cows in the intensive silvopastoral system had greater content of components, except for fat. Also, the difference in the chemical composition of milk had differential effects in the productive behavior of calves.

\section{REFERENCES}

Arce R., C.; Aranda I., E.M.; Osorio A., M.M.; González G., R.; Díaz R., P. \& Hinojosa C., J.A. (2017). Evaluación de parámetros productivos y reproductivos en un hato de doble propósito en Tabasco, México. Revista Mexicana de Ciencias Pecuarias. 8(1), 83-91.

Cárdenas J., E.G.; Maza A., L. \& Cardona J., A. (2015). Comportamiento productivo de terneros lactantes suplementados con maíz más torta de algodón en el departamento de Córdoba, Colombia. Revista Colombiana de Ciencia Animal. 7(2), 171-178.

Chirinos, Z.; Faría-Mármol, J.; Gómez, A.; León, L. \& Quiñones, R. (2011). Efecto de la estrategia de amamantamiento sobre el crecimiento de becerros y la producción de leche en un sistema de doble propósito del Zulia, Venezuela. Actas Iberoamericanas de Conservación Animal. 1, 268-271.

Díaz, C.; Sardiñas, L.; Castillo, C.; Padilla, C.; Jordán, V.; Martínez, Z.; Ruiz, V.; Díaz, S.; Moo, C.; Gómez, C.; Alpide, T.; Arjona, R. \& Ortega, G. (2014). Caracterización de ranchos ganaderos de Campeche, México. Resultados de proyectos de transferencia de tecnologías. Avances en Investigación Agropecuaria. 18(2), $41-61$

García, E. (1988). Modificaciones al sistema de clasificación climática de Köppen. Instituto de Geografia. México. Universidad Nacional Autónoma de México. 191 p

Guarneros A., R.; Gutiérrez O., E.; Bernal B., H.; Avalos R., R.; Castillo G., E. \& Olivares S., E. (2017). Acondicionamiento de becerros previo a la recría bajo pastoreo en trópico seco: efectos sobre el peso corporal y la condición sanitaria. Revista Mexicana de Ciencias Pecuarias. 8(4), 341-351.

Heras-Torres, J.G.; Osorio-Arce, M.M. \& Segura-Correa, J.C. (2008). Crecimiento de becerros en un sistema de doble propósito en el trópico húmedo de México. Revista Científica Maracaibo. 18(2), 170-174

Hernández R., R. \& Ponce C., P. (2004). Efecto del silvopastoreo como sistema sostenible de explotación bovina sobre la composición de la leche. Livestock Research for Rural Development. 16(6), Art. \#43. http://www.lrrd.org/lrrd16/6/hern16043.htm

Madrid-Bury, N.; González-Stagnaro, C.; Goicochea-Llaque, J.; González-Villalobos, D. \& Rodríguez-Urbina, M.A. (2007). Peso al nacimiento en hembras bovinas doble propósito. Revista de la Facultad de Agronomía (LUZ). 24, 690-708

Martínez C., C.J.; Cotera R., J. \& Abad Z., J. (2012). Características de la producción y comercialización de leche bovina en sistemas de doble propósito en Dobladero, Veracruz. Revista Mexicana de Agronegocios. 16(30), 816-824.

Martínez V., G.; Palacios F., J.A.; Bustamante G., J.J.; Rios U., A.; Eliezer V., M.V. \& Montaño B., M. (2010). Composición de leche de vacas Criollo, Guzerat y sus cruzas F1 y su relación con el peso al destete de las crías. Revista Mexicana de Ciencias Pecuarias. 1(4), 311-324.

Mohammed M., A.; Aguilar-Pérez, C.; Ayala-Burgos, A.; Bottini-Luzardo, M.; Solorio-Sánchez, F. \& Ku-Vera, J. (2016). Evaluation of milk composition and fresh soft cheese from an intensive silvopastoral system in the tropics. Dairy Science \& Technology. 96, 159-172.

Murgueitio, E.; Barahona, R.; Chará, J.; Flores M., X.; Mauricio, R. \& Molina J., J. (2015). The intensive silvopastoral systems in Latin America sustainable alternative to face climatic change in animal husbandry. Cuban Journal of Agricultural Science. 49(4), 541-554.

Orantes-Zebadúa, M.A.; Platas-Rosado, D.; Córdova-Avalos, V.; De los Santos-Lara, M.C. \& Córdova-Avalos, A. (2014). Caracterización de la ganadería de doble propósito en una región de Chiapas, México. Ecosistemas y Recursos Agropecuarios. 1(1), 49-58

Osorio-Arce, M.M. \& Segura-Correa, J.C. (2008). Factores que afectan el peso al nacer y al destete de becerros de doble propósito en el trópico. Livestock Research for Rural Development. 20(1), Art. \#15. http://www.lrrd.org/lrrd20/1/osor20015.htm

Prieto-Manrique, E.; Vargas-Sánchez, J.E.; Angulo-Arizala, J. \& Mahecha-Ledesma, L. (2016). Grasa y ácidos grasos en leche 
de vacas pastoreando, en cuatro sistemas de producción. Agronomía Mesoamericana. 28(1), 19-42.

Ramos, R.; Pabón, M. \& Carulla, J. (1998). Factores nutricionales y no nutricionales que determinan la composición de la leche. Revista de la Facultad de Medicina Veterinaria y de Zootecnia. 46(2), 2-7.

Rosendo-Ponce, A. \& Becerril-Pérez, C.M. (2015). Avance en el conocimiento del bovino criollo Lechero Tropical en México. Ecosistemas y Recursos Agropecuarios. 2(5), 233-249.

Saddy, J.; Depablos, L.; Colina, Y. \& Vargas, D. (2015). Evaluación de concentrados comerciales sobre el crecimiento de becerros doble propósito en la zona central de Venezuela. Zootecnia Tropical. 33(1), 89-96.

Salamanca C., A.; Quintero V., R. \& Benitez M., J. (2011). Características de crecimiento predestete en becerros del sistema doble propósito en el municipio de Arauca. Zootecnia Tropical. 29(4), 455-465.

SAS Institute. (2010). SAS 9.3 for Windows. Cary, North Carolina. United States of America.

Silva, T.; Takiya, C.; Vendramini, T.; Ferreira, J. \& Renno, F. (2016) Effects of dietary fibrolytic enzymes on chewing time, ruminal fermentation, and performance of mid-lactating dairy cows. Animal Feed Science and Technology. 221, 35-43.

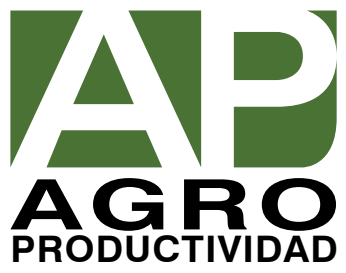

